\title{
Jaiphal Myristica fragrans (Houtt.)-A promising seed for pharmaceutical industries
}

\author{
ISSN: $2640-7760$ \\ Received: 07 February, 2020 \\ Accepted: 20 March, 2020 \\ Published: 21 March, 2020
}

DOI: https://dx.doi.org/10.17352/ijpsdr

Ankita Chakravarty, Jai Gopal Sharma*

Department of Biotechnology, Delhi Technological University, Delhi - 110042, India
*Corresponding author: Jai Gopal Sharma, Department of Biotechnology, Delhi Technological University, Delhi - 110042, India,

E-mail: sharmajaigopal@gmail.com

https://www.peertechz.com

Check for updates
The evergreen dark - leaved aromatic dioecious Myristica fragrans Houtt. (1774) is a native tree of Indonesia and is also found in tropical countries like India (Kerala), Malaysia (Penang inland), Taiwan etc. It is popularly known as jaiphal and belongs to the family Myristicaceae. It has spreading branches and a yellow fleshy fruit. The fruits are sources of two valuable spices-nutmeg derived from the fruit and mace obtained from the seed cover. The spices are used in cooking to improve the taste and flavour of delicious dishes. Besides these have many pharmaceutical applications. There is mention of application of jaiphal in folk medicine for various purposes viz. anti-thrombotic, anti-tumor, anti-inflammatory etc. [1]. In Unani medicine, Jaiphal is used to manage male sexual disorders [2]. Nutmeg is a rich source of essential oil and nutmeg butter. It contains $25-30 \%$ fixed oils and $5-15 \%$ volatile oils. The presence of limonene, sabinene, camphrene, eugenol, myristic acid, myristicin, lignin etc. in nutmeg makes it useful in medicine [3].

Jaiphal has anti-diabetic, anti-carcinogenic, antidepressant, anti-obesity, anti-diarrheal, hepatoprotective properties; it is used in enhancing memory skills. Jaiphal has also anti-inflammatory and anti-analgesic effects. Essential oil derived from both mace and nutmeg is used in the remedy of sprains, muscle pulls etc. The limonene is anticarcinogenic, anti-oxidant; sabinene is anti-inflammatory and anti-microbial, quercitin is anti-inflammatory. Myristicin present in jaiphal has anti-oxidant property. Aril parts of jaiphal possess strong antioxidant activity as it has the capacity to inhibit lipid peroxidation and superoxide radical scavenging activity. Myristicin plays significant role in memory enhancing activity of jaiphal $[4,5]$.

Jaiphal is effective to cure peptic ulcer as it reduces the total acidity of gastric secretions without any side effect [4]. Macelignan, the lignin obtained from nutmeg is the natural, active constituent of anti-diabetic property. It enhances the lipid per oxidation and insulin metabolism that reduces the stress generated by the Type 2 diabetes agent Peroxisome Proliferative Receptor (PARR). The application of essential oil of jaiphal is effective against in breast cancer, epidermal skin cancer and colon cancer cell lines. The ethanolic extract of jaiphal $(70 \%)$ is useful against human cancer cell lines. The presence of minerals like, calcium, iron, magnesium, selenium, silver, gold etc. enhances the medicinal value of the jaiphal [6].

Jaiphal also has industrial applications [7]. It is a useful preservative as it has anti-microbial activity. It is very effective against various spoilage pathogens especially microbes responsible for food poisoning. It shows inhibition against both plant and animal pathogens. It has anti-fungal, anti-bacterial activities. The presence of various volatile components in essential oil and ethyl acetate in the flesh of jaipahl is effective against selected strains of gram positive and gram negative bacteria; it also inhibits the bacterial spores. Malbaricone present in jaiphal is responsible for the anti-microbial activity. Myristicin in combination with pyrethrum is the active constituent responsible for the insecticidal activity [8].

\section{References}

1. Chung J, Choo J, Lee M, Hwang J (2006) Anticariogenic activity of macelignan isolated from Myristica fragrans (nutmeg) against Streptococcus mutans. Phytomedicine 13: 261-266. Link: https://bit.ly/3dv15Lf

2. Ali M, Zaigham M, Ikram M (2018) Phyto-pharmacological potential of Jaiphal (Myristica fragrans Houtt): A spice of medicinal importance and its utilization in Unani Medicine. Int J Green Pharm 12: 26-36. Link: https://bit.ly/2vUC3UY

3. Jaiswal P, Kumar P, Singh V, Singh D (2009) Biological effects of Myristica fragrans. ARBS Annu Rev Biomed Sci 11: 21-29. Link: https://bit.ly/3amiYtx

4. Grover J, Khandkar S, Vats V, Dhunnoo Y, Das D (2002) Pharmacological studies on Myristica fragrans Antidiarrheal, hypnotic, analgesic and hemodynamic 
(blood pressure) parameters. Methods Find Exp Clin Pharmacol 24: 675-680 Link: https://bit.ly/3bxsYRb

5. Honey J, Arya K, Sindhu TJ, Syamjith P, Vinod KR, et al. (2016) Descriptive Review on Myristica fragrans Houtt. J Drugs Medicines 8: 35-43. Link: https://bit.ly/2vTGzD8

6. Ann Thomas R, Krishnakumari S (2015) Proximate analysis and mineral composition of Myristica fragrans seeds. J Pharmacogn Phytochem 3: 39-42 Link: https://bit.ly/2WLFCYj
7. Kazeem M, Akanji M, Hafizur R, Choudhary M (2012) Antiglycation, antioxidant and toxicological potential of polyphenol extracts of alligator pepper, ginger and nutmeg from Nigeria. Asian Pac J Trop Biomed 2: 727-732. Link: https://bit.ly/33MwMLr

8. Sachan AKR, Kumar S, Kumari, K, Singh, D (2018) Medicinal uses of spices used in our traditional culture: Worldwide. J Med Plants Stud 6: 116-122. Link: https://bit.ly/3dz1mgm

\section{Discover a bigger Impact and Visibility of your article publication with}

\section{Peertechz Publications}

\section{Highlights}

* Signatory publisher of ORCID

* Signatory Publisher of DORA (San Francisco Declaration on Research Assessment)

* Articles archived in worlds' renowned service providers such as Portico, CNKI, AGRIS, TDNet, Base (Bielefeld University Library), CrossRef, Scilit, J-Gate etc.

* Journals indexed in ICMJE, SHERPA/ROMEO, Google Scholar etc.

- OAI-PMH (Open Archives Initiative Protocol for Metadata Harvesting)

* Dedicated Editorial Board for every journa

* Accurate and rapid peer-review process

- Increased citations of published articles through promotions

* Reduced timeline for article publication

Submit your articles and experience a new surge in publication services (https://www.peertechz.com/submission).

Peertechz journals wishes everlasting success in your every endeavours.

Copyright: @ 2020 Chakravarty A, et al. This is an open-access article distributed under the terms of the Creative Commons Attribution License, which permits unrestricted use, distribution, and reproduction in any medium, provided the original author and source are credited. 